HELMINTHOLOGIA, 53, 3: 248 - 256, 2016

\title{
Seasonality and host-parasite interrelationship of Hysterothylacium aduncum (Nematoda) in whiting Merlangius merlangus off the southern and northern coasts of the Black Sea
}

\author{
A. ÖZER ${ }^{1 *}$, Y. M. KORNYYCHUK², V. YURAKHNO², T. ÖZTÜRK'
}

'Sinop University, Faculty of Fisheries and Aquatic Sciences, 57000 Sinop, Turkey, E-mail: aozer@sinop.edu.tr, ${ }^{2}$ A. O. Kovalevsky Institute of Marine Biological Research of RAS, 2 Nakhimov ave., Sevastopol 299011, Russia

\section{Article info}

Received March 11, 2016 Accepted June 7, 2016

\begin{abstract}
Summary
In the present study, we investigated the comparative infection levels, ecology and host-parasite interrelationship of a nematode Hysterothylacium aduncum (Rudolphi, 1802) in whiting, Merlangius merlangus (L., 1758) in southern (Sinop) and northern (Balaklava Bay) coasts of the Black Sea for the first time. Fish were collected throughout a period from May 2011 to March 2014 from local fishermen. A total of 690 fish specimens near Sinop and 423 fish near Balaklava Bay were examined for parasites. Hysterothylacium aduncum was the only nematode species identified in the digestive tract of the Black Sea whiting Merlangius merlangus. Prevalence of infection, mean intensity and mean abundance values were determined according to season, length classes and sex of fish at both localities. These infection indices were always higher in Sinop samples than those of Balaklava Bay samples.

Keywords: Hysterothylacium aduncum; parasite ecology; Merlangius merlangus; Black Sea
\end{abstract}

\section{Introduction}

Hysterothylacium aduncum (Rudolphi, 1802) is a generalist nematode registered from many marine fish species (Andersen 1993) and it occurs in around 30 fish species, including the whiting, Merlangius merlangus (L., 1758), in the Black Sea (Kornyychuk \& Zavjalov, 2005; Öztürk, 2005; Özer, 2007; Gaevskaya et al., 2010; Özer et al., 2012; Özer \& Olguner, 2013; Tepe \& Oğuz, 2013). It lives as sexually mature adults in the digestive tracts of marine teleost fishes (Navone et al., 1998) and its larvae are known to occur in marine invertebrates and in fish (Koie, 1993). The 3rd-stage larvae have been found encapsulated in the mesentery and viscera of a wide range of fishes that act as transport hosts (Berland, 1961; Koie, 1993). The first intermediate hosts for $H$. aduncum are crustaceans, such as copepods, amphipods, decapods, shrimps, euphasiids, and isopods (Koie, 1993; Marcogliese, 1996). Ga- doids are generally believed to be the main final hosts (Berland, 1961). Predatory fish, like gadoids, largely acquire and accumulate different stages of $H$. aduncum by ingesting crustaceans, chaetognaths and small fish species that are infected and serve as carriers (Klimpel et al., 2003; Klimpel \& Rückert, 2005).Whiting is a commercially important fish species and widely distributed in the eastern North Atlantic Ocean, the northern Mediterranean, western Baltic and the Black Sea (ICES, 2006). It is particularly distributed along Romanian, Bulgarian, Turkish, Ukrainian, Russian and Caucasus coasts in the Black Sea (Burdak, 1960; Svetovidov, 1964; Gönener \& Bilgin, 2010; Özer et al., 2014).

The objective of the present study is to investigate the infection levels of $H$. aduncum in $M$. merlangus from the southern and northern Black Sea coasts and to provide first detailed comparative ecological analysis of $H$. aduncum infection of whiting at both localities. 


\section{Materials and Methods}

\section{Study area and explanatory variables}

Whiting samples were collected throughout a period from May 2011 to March 2014 from commercial fishing vessels in the southern Black Sea off Sinop (N $42^{\circ} 05^{\prime} 68^{\prime \prime}$ E 35 $5^{\circ} 10^{\prime} 55^{\prime \prime}$ ) and northern Black Sea in Balaklava Bay (N 44 49' 54" E $33^{\circ} 59^{\prime} 48^{\prime \prime}$ ). In total, 690 fish from Sinop and 423 from Balaklava Bay were measured to the nearest $\mathrm{cm}$ of total length and then examined for parasites. Fish were transferred to the laboratories at Sinop University, Faculty of Fisheries and Aquatic Sciences and the A.O. Kovalevsky Institute of Marine Biological Research of RAS in Sevastopol and then all fish were examined for parasites within $24 \mathrm{~h}$ of sampling. Examinations were conducted on liver, stomach, caeca, intestine and its contents, swim bladder and gonads in accordance with Navone et al. (1998). All specimens of nematodes at different developmental stages (L3, L4 and adults) were collected and counted by screening whole smears of digestive tract under a dissecting microscope and identified at x40 magnification after washing the obtained larvae and adults repeatedly in $0.9 \%$ saline solution, fixing in $70 \%$ ethanol and clearing with lactophenol. Taxonomic features indicated by Berland (1961), Petter and Maillard (1988), Koie (1993) and Navone et al. (1998) in discriminating parasites to developmental stages and species level were followed and identification was conducted using Olympus microscope (BX53). Water temperature $\left({ }^{\circ} \mathrm{C}\right)$ values were measured monthly using a YSI Professional Plus water quality instrument during one year period of $2012-2013$.

\section{Statistical analyses}

All developmental stages were lumped and the prevalence, mean intensity and mean abundance values were determined according to Bush et al. (1997). Quantitative Parasitology 3.0 software (Reiczigel \& Ryzsa, 2005) was used to calculate Sterne's exact 95\% confidence limits for prevalence, bootstrap $95 \%$ confidence limits (number of bootstrap replications $=2.000$ ) for mean abundances, mean intensity, median intensity, variance to mean ratio and exponent of the negative binomial $(k)$. Difference in prevalence values between two fish populations from two sampling localities and between two fish sexes were determined by the exact unconditional test that maintains the prescribed type I error rate, which has a higher statistical power in a small sample size $(\mathrm{N}<100)$. Differences in prevalence values between sampling seasons, age and length categories were determined using the Fisher's exact test while the differences in mean abundance and intensity were performed by the bootstrap two-sample $t$ test.

\section{Results}

Hysterothylacium aduncum (Rudolphi, 1802) was the only nematode identified as $3^{\text {rd }}$ stage larvae encysted in mesentery and viscera and as $4^{\text {th }}$ stage larvae and adults in the digestive tract of whiting Merlangius merlangus collected from Sinop coasts and Balaklava Bay in the Black Sea. Infection parameters of the 690 fish from Sinop and 423 fish from Balaklava Bay were determined (Table 1). Prevalence of infection, mean intensity and mean abundance values in Sinop samples were higher than those in Balaklava Bay samples.

Seasonal prevalence, mean intensity and mean abundance values of $H$. aduncum infecting $M$. merlangus at both localities were determined (Table 2). Seasonal value of prevalence was between $72.7 \%$ and $88.3 \%$, mean intensity 5.3 and 14.4 , and mean abundance 4.3 and 11.8 in the fish samples from Sinop coasts. When the samples from Balaklava Bay were evaluated in terms of these infection indices, seasonal value of prevalence was found to be between $11.3 \%$ and $46.1 \%$, mean intensity 1.5 and 3.7 , and mean abundance 0.2 and 1.7. Seasonal differences in prevalence and median intensity (variable) of whiting with $H$. aduncum in Sinop and Balaklava Bay samples were compared (Table 3); there was statistically significant differences in prevalence $(p=0.001)$ and median intensity $(p=0.012)$ between seasons in Sinop samples and similar significant differences were also obtained in prevalence $(p=0.000)$ and median intensity $(p=0.011)$ between seasons in Balaklava Bay samples. Seasonal differences in prevalence, mean/median intensity and mean abundance of $H$. aduncum between Sinop and Balaklava Bay samples were compared (Table 4). Statistically significant differences between sampling locations were determined in prevalence $(p<0.05)$ values for all seasons; mean intensity $(p<0.05)$ values in spring and winter; median intensity $(p<0.05)$ values in all seasons except summer and mean abundance $(p<0.05)$ values in all seasons except autumn.

Prevalence, mean intensity and mean abundance values of $H$. aduncum infecting three length classes of $M$. merlangus at both localities were determined (Table 2). Prevalence was between $70.9 \%$ and $88.7 \%$, mean intensity 10.3 and 20.6 , and mean abundance 8.3 and 18.1 in the Turkish coast. On the other hand, for fish samples from Balaklava Bay, prevalence was between $24.8 \%$ and $43.6 \%$, mean intensity 1.8 and 5.0 , and mean abundance 0.6 and 2.2. The differences in prevalence and median intensity (variable) of $H$. aduncum between Sinop and Balaklava Bay samples in terms of fish length classes are compared (Table 3); there was statistically significant differences in prevalence $(p=0.000)$ and median intensity $(p=0.000)$ between length classes in Sinop samples and similar significant differences were also obtained in prevalence $(p=0.007)$ and median intensity $(p=0.000)$ between length classes in Balaklava Bay samples. The differences in prevalence, mean/median intensity and mean abundance of $H$. aduncum between Sinop and Balaklava Bay samples in terms of fish length classes are compared (Table 4). Statistically significant differences between sampling localities are determined in prevalence $(p<0.05)$ values in all fish length classes; however, these significant differences in mean intensity $(p<0.05)$, median intensity $(p<0.05)$ and mean abundance $(p<0.05)$ values were limited to larger fish length classes $15-18 \mathrm{~cm}$ and $>18 \mathrm{~cm}$ at both localities. 


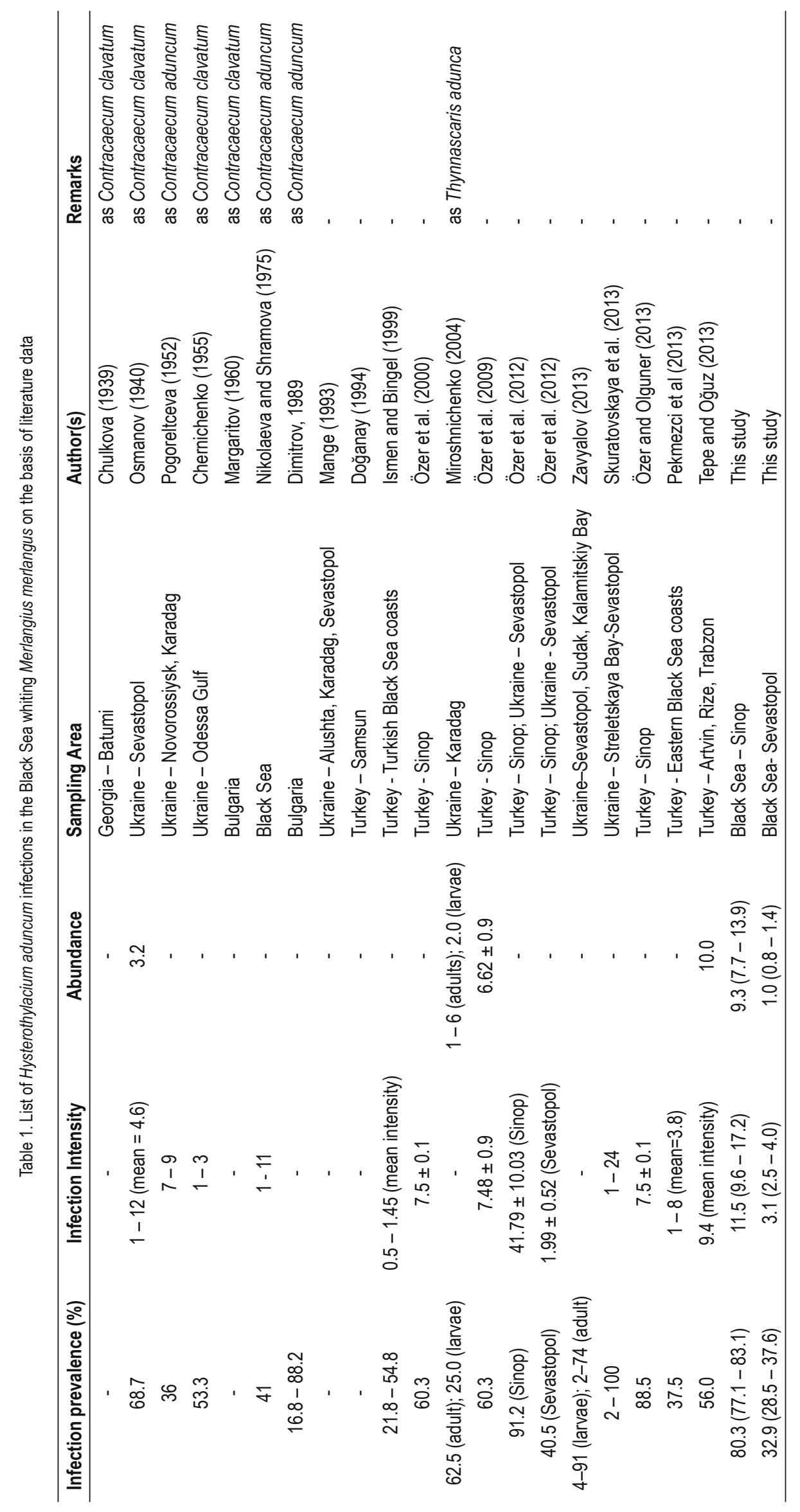




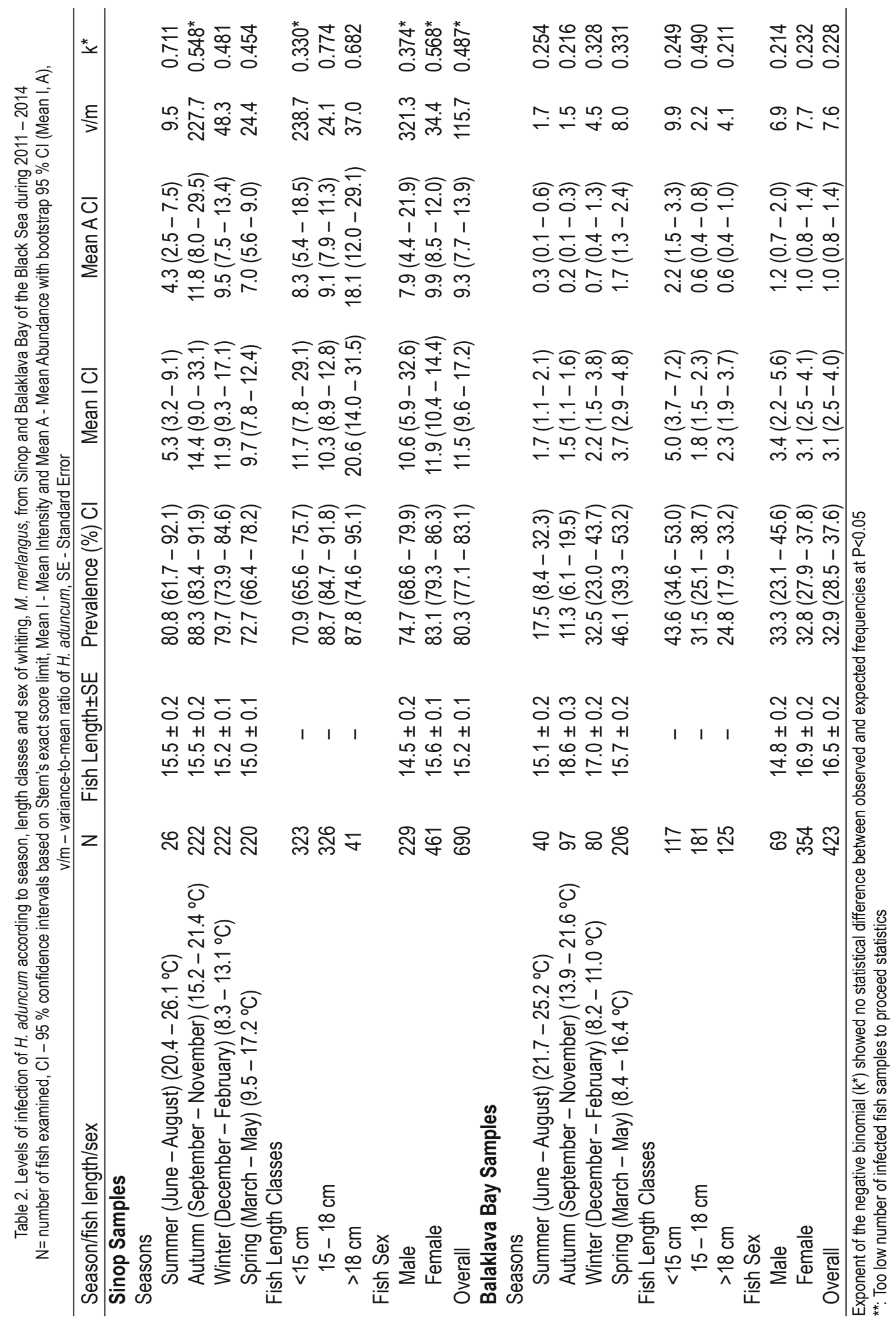


Table 3. Comparative statistical differences in prevalence, mean intensity, median intensity and mean abundance of $H$. aduncum in Sinop and Balaklava Bay samples relative to season, fish size and sex

\begin{tabular}{llcccc}
\hline Fish samples & Variable & $\begin{array}{c}\text { Prevalence } \\
(\%)\end{array}$ & Mean Intensity & Median Intensity & Mean Abundance \\
\hline Sinop & Seasons & $0.001^{*}$ & - & $0.012^{*}$ & - \\
& Length classes & $0.000^{*}$ & - & $0.000^{*}$ & - \\
& Sex & $0.009^{*}$ & 0.712 & $0.010^{*}$ & 0.574 \\
Balaklava Bay & Seasons & $0.000^{*}$ & - & $0.011^{*}$ & - \\
& Length classes & $0.007^{*}$ & - & $0.000^{*}$ & - \\
& Sex & 1.000 & 0.668 & 1.000 & 0.700 \\
\hline
\end{tabular}

${ }^{*}$ level of significance with $p<0.05$

Prevalence, mean intensity and mean abundance values of $H$. aduncum infecting $M$. merlangus different sexes at both localities were determined (Table 2). Of the above mentioned infection indices, only prevalence and median intensity values between female and male whiting in Sinop samples had statistically significant differences $(p<0.05)$ (Table 3$)$; on the other hand, there was no statistically significant $(p>0.05)$ difference in none of the infection indices between female and male whiting in Balaklava Bay samples (Table 3). Differences in prevalence, mean/median intensity and mean abundance of $H$. aduncum between Sinop and Balaklava Bay samples in terms of the sex of fish were compared (Table 4). The differences were statistically significant between sampling locations in prevalence $(p<0.05)$ and median intensity $(p<0.05)$ values in females as well as in males. However, mean intensity and mean abundance did not change in female and male fish groups from both of the localities (Table 4).

\section{Discussion}

The present study has revealed the seasonality and host-parasite interrelationships of $H$. aduncum found in the digestive tract of whiting $M$. merlangus and compared its occurrences between two geographically distant southern and northern localities of the Black Sea. In 3-year period of our research study, $H$. aduncum was the only nematode species found in the Black Sea whiting $M$. merlangus, at both larval and adult stages. Black Sea whiting is one of numerous hosts for $H$. aduncum and it is a representative of cods feeding on small fish and planktonic crustaceans such as copepods, amphipods, decapods, shrimps, euphasiids, and isopods which are the intermediate hosts of this parasite species. It was reported by Loboda and Khvorov (2004) that $12.5 \%$ of Sagitta setosa in the Black Sea acted as an additional host in the life cycle of $H$. aduncum and nematode larvae are able to grow

\begin{tabular}{|c|c|c|c|c|}
\hline Variable & $\begin{array}{c}\text { Prevalence } \\
(\%)\end{array}$ & $\begin{array}{c}\text { Mean } \\
\text { Intensity }\end{array}$ & $\begin{array}{l}\text { Median } \\
\text { Intensity }\end{array}$ & $\begin{array}{c}\text { Mean } \\
\text { Abundance }\end{array}$ \\
\hline \multicolumn{5}{|l|}{ Seasons } \\
\hline Spring & $0.000^{*}$ & $0.000^{*}$ & $0.000^{*}$ & $0.000^{*}$ \\
\hline Summer & $0.000^{*}$ & 0.067 & 0.084 & $0.051^{*}$ \\
\hline Autumn & $0.000^{*}$ & 0.313 & $0.001^{*}$ & 0.281 \\
\hline Winter & $0.000^{*}$ & $0.002^{*}$ & $0.000^{*}$ & $0.000^{*}$ \\
\hline \multicolumn{5}{|l|}{ Length classes } \\
\hline$<15 \mathrm{~cm}$ & $0.000^{*}$ & 0.253 & 0.086 & 0.206 \\
\hline $15-18 \mathrm{~cm}$ & $0.000^{*}$ & $0.000^{*}$ & $0.000^{*}$ & $0.000^{*}$ \\
\hline$>18 \mathrm{~cm}$ & $0.000^{*}$ & $0.011^{*}$ & $0.013^{*}$ & $0.000^{*}$ \\
\hline \multicolumn{5}{|l|}{ Sex } \\
\hline Female & $0.000^{*}$ & $0.000^{*}$ & $0.000^{*}$ & $0.000^{*}$ \\
\hline Male & $0.000^{*}$ & 0.374 & $0.042^{*}$ & 0.377 \\
\hline
\end{tabular}


in sagittas. Gaevskaya et al. (2012a) also reported that copepods Pleurobrachia rhodopis and Pseudocalanus elongates and chaetognath $S$. setosa are the first and second intermediate hosts, respectively, for $H$. aduncum in the Black Sea and all year round presence of above mentioned species have been reported and reviewed extensively in Sinop coasts of the Black Sea where this study was conducted (Bat et al., 2007a,b, 2011). Therefore, fish may have become infected with $H$. aduncum larvae by consuming those previously infected intermediate hosts (Klimpel et al., 2003; Klimpel \& Rückert, 2005). Overall infection values determined in the present study were about 3 times higher in Sinop samples than that of Balaklava Bay samples, and the differences between localities were statistically significant. Previous studies (see Table 1 for details) on $H$. aduncum infections in $M$. merlangus in Sinop coasts of the Black Sea reported high infection prevalence levels from $37.5 \%$ to $100.0 \%$ and mean intensities from 3.8 to 12.8 per infected fish (Özer et al., 2000; Özer et al., 2009; Özer \& Olguner, 2013; Tepe \& Oğuz, 2013; Pekmezci et al., 2013). Skuratovskaya et al. (2013) reported infection prevalence levels of $H$. aduncum ranging between $46-65 \%$ and $1-12$ per infected $M$. merlangus collected from Crimean coast of the Black Sea. It is known that the Black Sea whiting is divided into different populations due to their reproductive isolation which is determined by spatially isolated spawning areas (Burdak, 1960), and regional differences were expected in the component structure of the Black Sea whiting parasites. Thus, we can assume that 3 times higher infection levels in Sinop samples than that of Balaklava Bay samples are resulted from this situation. Moreover, more than $85 \%$ of total amount of whiting harvest in the Black Sea is caught in Turkey, mainly near Sinop, while other Black Sea countries use only small part of whiting stocks. Thus, it can be assumed that whiting stocks near Sinop coasts might be affecting the infection pattern with $H$. aduncum by having more intermediate hosts available along with relatively higher seasonal temperature values facilitating food consumption of fish in Sinop coastal areas. Wide range of infection levels reported for $H$. aduncum in many different fish hosts investigated in different geographical parts of the Black Sea show that this parasite species has not only the ability of wide dispersion to different host species but also different geographic populations in the Black Sea. However, given the high level of infection throughout three-year period, it is clear that $M$. merlangus serve as at least one of main hosts for $H$. aduncum. Parasites have been useful in separating fish populations in other geographical regions (MacKenzie, 2002; Timi et al., 2005) and future studies should focus on genetic differences of parasites for further evidence in discriminating fish stocks in the southern and northern zones of the Black Sea.

Hysterothylacium aduncum occurred all year-round in both Sinop and Balaklava Bay samples, autumn in Sinop samples and spring in Balaklava Bay samples were the most appropriate season for both its prevalence of infection and intensities. Despite determined statistically significant differences among seasons at both localities, obtained results indicate that $H$. aduncum has the ability of all year-round infection capability which is not so affected from environmental factors, especially from temperature that is accepted to be one of the triggering factors for food consumption of fish host over infected intermediate hosts. In the literature, the highest prevalence and mean intensity ( $54.8 \%$ and 1.40 , respectively) for this nematode in Black Sea whiting was in the warm months of July/August when collected along the continental shelf of Turkish coast of the Black Sea (İşmen \& Bingel, 1999). On the other hand, in a study conducted by Andersen (1993), it was reported that $H$. aduncum infected cod, Gadus morhua, through all-year period with some peaks in colder seasons. Valero et al. (2000) reported minimum and maximum infection parameter in winter and spring, respectively, in blue whiting Micromesistius potassou collected from the western Mediterranean Sea, off southern Spain. Adroher et al. (1996) also reported a year-round infection for $H$. aduncum in horse mackerel Trachurus trachurus in the Mediterranean Sea with several peaks at moderate water temperature values. Kalay et al. (2009) also stated high prevalence and mean intensity levels of $H$. aduncum invasion of Mediterranean fishes Sparus aurata and Diplodus vulgaris during the period of moderate water temperature (June and March, respectively). The results of this study also correspond with the fact that $H$. aduncum is a moderate water temperature parasite better surviving at $16{ }^{\circ} \mathrm{C}$ (Adroher et al., 1996). As Smith (1983) stated that anisakid nematodes disperse their eggs via final hosts throughout the year, and they may develop and hatch at any time and seasonal variations in infection levels of anisakid nematodes were reasoned due to changes in the population of infected zooplankton serving as intermediate hosts (Smith \& Wootten, 1978). One of the most important factors influencing the composition of the parasite fauna is age and size of a host (Özer \& Öztürk, 2005). The results of this study indicated that larger hosts had more infection and parasite load and similarly in a study by Adroher et al. (1996) increasing infection levels of $H$. aduncum were reported in close association with increasing size of horse mackerel. Rello et al. (2008) reported increases, though not statistically significant, at prevalence and intensities of infection of $H$. aduncum by length of Sardina pilchardus from the southern and eastern coasts of Spain. Anderson and Gordon (1982) reported that the higher parasitism observed in larger fish over smaller ones might be a result of change in diet of the fish and higher activity to search for food. Morsy et al. (2011) also found similar results indicating that larger fish were able to compete better for food than the smaller fish groups which meant that when there is more contact with food there is a higher tendency of getting infected with parasites, and this could be due to an accumulation of parasites in the host throughout its life (Bussmann \& Ehrich, 1979).

Parasites may infect both sexes differently, because male and female fish often have different feeding habits (Rohde, 1993). In our study, host sex did not have a significant influence on the infection parameters of $H$. aduncum in $M$. merlangus, suggesting that habitat use and diet are similar for both sexes of this species at both 
sampling zones. In detail, the infection parameters calculated for female fish was higher in Sinop samples and the situation was the reverse in Balaklava Bay samples in which male fish had higher infection values, both without any significance, except prevalence of infection in Sinop samples.

In conclusion, $H$. aduncum infected the digestive tract, mesentery and viscera of whiting. It occurred all year-round in both Sinop and Balaklava Bay, though the most appropriate seasons at both sampling localities were different. Larger length classes of Black Sea whiting had more infection values at both localities; however, this situation was reverse in the effect of host sex over its occurrence. In the present study, higher infections obtained from Sinop samples than that of Balaklava Bay samples may reflect that whiting populations at both sampling localities are different as a result of their reproductive isolation determined by spatially isolated spawning areas, and as a result, regional differences can be expected in infection structure of the Black Sea whiting parasites. Future studies should focus on genetic differences of parasites for further evidence in discriminating fish stocks in the southern and northern zones of the Black Sea. Whiting is a fish species frequently consumed by of Black Sea region and thus far, there is no evidence that $H$. aduncum larvae are pathogenic in humans and Huang (1988) reported that this nematode cannot survive at human body temperature.

\section{Acknowledgement}

Authors are grateful to The Scientific and Technological Research Council (TÜBITAK) of Turkey and National Academy of Sciences of Ukraine (NASU) for their financial support with the project number of 1100475

\section{References}

Adroher, F.J., Valero, A., Ruiz-Valero, J., Iglesias, L. (1996): Larval anisakids (Nematoda: Ascaridoidea) in horse mackerel (Trachurus trachurus) from the fish market in Granada (Spain). Parasitol. Res., 82: 253 - 256. DOI: 10.1007/s004360050105

ANDERSEN, K. (1993): Hysterothylacium aduncum (Rudolphi, 1862) infection in cod from the Oslofjord; seasonal occurrence of thirdand fourth-stage larvae as well as adult worms. Parasitol. Res., 79: 67 - 72. DOI: 10.1007/BF00931220

Anderson, R.M., GoRdon, D.M. (1982): Processes influencing the parasite numbers within host populations with special emphasis on parasite induced host mortalities. Parasitology, 85: 373 - 398. DOI: $10.1017 /$ S0031182000055347

BAt, L., ŞAHIN, F., Üstün, F., KIdEYŞ, A., SATILmIŞ, H.H. (2007a): The qualitative and quantitative distribution in phytoplankton and zooplankton of southern Black Sea of cape Sinop, Turkey in 1999 2000. In IEEE Oceans'07, IEEE Catalogue Number: 07EX1527C; ISBN Number: 1-4244-0635-8; Library on Congress: 2006932314, $6 \mathrm{p}$.
Bat, L., Şahin, F., Satıllmış, H.H., Üstün, F., BIRIncI Özdemir, Z., KıdEYŞ, A.E., Shulman, G.E. (2007b): The changed ecosystem of the Black Sea and its impact on anchovy fisheries. J. FisheriesSciences.com, 1: 191 - 227 (In Turkish with English summary)

Bat, L., Sezgin, M., Satilmiş, H.H., Şahin, F., Üstün, F., Birincl ÖzDemIr, Z., GöKKURT BAKI, O. (2011): Biological Diversity of the Turkish Black Sea Coast. Turk. J. Fish. Aquat. Sci., 11: 683 - 692 BerLand, B. (1961): Nematodes from some Norwegian marine fishes. Sarsia 2: 1 - 52. DOI: 10.1080/00364827.1961.10410245

BerLand, B. (1991): Hysterothylacium aduncum (Nematoda) in fish. In International Council for the Exploration of the Sea, Leaflet No. 44: $1-4$

BURDAK, V.D. (1960): Biology of the Black Sea whiting Odontogadus merlangus euxinus Nordmann. Ph.D. thesis, USSR Academy of Science, Ukraine

Bush, A.O., Lafferty, K.D., LotZ, J.M., Shostak, A.W. (1997): Parasitology meets ecology on its own terms: Margolis et al. revisited. J. Parasitol., 83: 575 - 583. DOI: 10.2307/3284227

Bussmann, B., EHRICH, S. (1979): Investigations on infestation of blue whiting (Micromesistius poutassou) with larval Anisakis sp. (Nematoda: Ascaridida). Arch. Fischer.-Wiss., 29: 155 - 165.

Chernichenko, A.S. (1955): Materials on Odessa Gulf fish parasite fauna. Trudi Odesskogo Univ Biol Ser., 45: 211-222.

Chulkova, V.N. (1939): Parasite fauna of fishes near Batumi. Uch. Zapiski Len. Univ., 43: 21 - 31 (In Russian with English summary]. Dimitrov, G.I. (1989): Investigations of the helminths of fish of the Bulgarian Black Sea coast. Ph.D. thesis, Bulgarian Academy of Sciences, Bulgaria

DoĞANAY, A. (1994): A record of Hysterothylacium aduncum (Rudolphi, 1802) in cod-fish (Gadus sp.) from Black Sea. Ankara Univ. J. Vet. Fac., 41: 208 - 217 (In Turkish with English summary) Gaevskaya, A.V., Kornyichuk, J.M., Machkevsky, V.K., Pronkina, N.V., Polyakova, T.A., Mordvinova, T.N., Popyuk, M.P. (2010): Characters of parasite system function of Hysterothylacium aduncum (Nematoda: Anisakidae) in the Black Sea. Mar. Ecol. J., 2: 37 - 48 (In Russian with English summary)

Gaevskaya, A.V., Korniychuk, J.M., Temnikh, A.V., Pronkina, N.V. (2012a) The Black Sea ctenophores and chaetognaths in life cycle of nematode Hysterothylacium aduncum (Nematoda: Anisakidae). Mar. Ecol. J., 1: 25 - 28 (In Russian with English summary)

Gaevskaya, A.V., Dmitrieva, E.V., Polyakova, T.A., Pronkina, N.V., PopJuk, N.P. (2012b): Effect of oil pollution on the species community structure and population of helminths in fish from Kerch strait. Materialy VII mezhdunarodnoy conferentsii "Sovremenniye ribokhozyastvenniye $i$ ekologicheskiye problemy Azovo-Chernomorskogo regiona" (20 - 23 June, Kerch). P. 40 - 46 (In Russian) GöNENER, S., BILGIN, S. (2010): The distribution and biomass of catchable fish caught by commercial bottom trawl in the Black Sea (Sinop-İnceburun Region). J. Fisheriessciences.com 4: 195 - 208. DOI: 10.3153/jfscom.2010021 (In Turkish with English summary) HuAng, W. (1988): Anisakides et anisakidoses humaines. Deuxieme partie: Enquete sur les anisakids de poissons commerciaux 
du march parisien. Ann. Parasitol. Hum. Comp., 63:197 - 208

International Council for the Exploration of the Sea (ICES) (2006): Whiting. Merlangius merlangus. pp. 1 - 7. Available at http://www. ices.dk/explore-us/projects/EU-RFP/Pages/ICES-FlshMap.aspx. Accessed 01 November 2015

İşMen, A., BIngel, F. (1999): Nematode infection in the whiting Merlangius merlangus euxinus off Turkish Coast of the Black Sea. Fish. Res., 42: 183 - 189. DOI:10.1016/S0165-7836(99)00022-3 Kalay, M., Dönmez, A.E., Koyuncu, C.E., Genç, E., Şahin, G. (2009): Seasonal variation of Hysterothylacium aduncum (Nematoda: Raphidascarididae) infestation in sparid fishes in the Northeast Mediterranean Sea. Turk. J. Vet. Anim. Sci., 33: 517 - 523. DOI:10.3906/vet-0703-12

Klimpel, S., Seehagen, A., Palm, H.W. (2003): Metazoan parasites and feeding behaviour of four small-sized fish species from the central North Sea. Parasitol. Res., 91: 290 - 207. DOI: 10.1007/ s00436-003-0957-8

KLIMPEL, S., RüCKERT, S. (2005): Life cycle strategy of Hysterothylacium aduncum to become the most abundant anisakid fish nematoda in the North Sea. Parasitol. Res., 97: 141 - 149. DOI: 10.1007/s00436-005-1407-6

KoIE, M. (1993): Aspects of the life cycle and morphology of Hysterothylacium aduncum (Rudolphi, 1802) (Nematoda, Ascaridoidea, Anisakidae). Can. J. Zool., 71: 1289 - 1296. DOI: 10.1139/ z93-178

KoRnYYCHUK, Y.M., ZAVJALOV, A.V. (2005): Helminths of the Black Sea sprat Sprattus sprattus phalericus Risso near the Crimean coasts. Ekol. Morya, 69: 20 - 24 (In Russian with English summary) LobodA, A.P., Khvorov, S.A. (2004): First find of nematoda Hysterothylacium aduncum (Nematoda) larvae from sagitta Sagitta setosa in the Black Sea. Vestn. Zool., 38: 75 - 76

MACKENZIE, K. (2002): Parasites as biological tags in population studies of marine organisms: An update. Parasitology, 124: 153 163. DOI:10.1016/j.jppaw.2013.11.001

Mange, S. (1993): Parasite fauna of fishes off Alushta, Blask Sea. PhD Thesis, Kiev, Ukraine.

MARCogliese, D.J. (1996): Larval nematodes infection marine crustaceans in eastern Canada. 3. Hysterothylacium aduncum. J. Helm. Soc. Wash., 63:12 - 18

Margaritov, N.M. (1960): Parasites of some our marine fishes. Trudi Nauchniy Ribopromislovoy Stanciy Varny, 2: 195 - 213 (In Bulgarian with English summary)

MIROSHNICHENKO, A.I. (2004): Parasites of marine fishes of Karadag Natural Reserve. In: Karadag. Gidrobiological Researchers Book 2. Simferopol. pp: $86-101$

Morsy, K., Abdel-Monem, S., Abdel-Ghaffar, F., Bashtar, A-R., Al-Ghamdi, A., Abdel-Gaber, R. (2011): First record of Benedenia sciaenae (Monogenea: Capsalidae) infecting the brown-spotted grouper fish Epinephelus chlorostigma (Family: Serranidae) from the Red Sea in Egypt. Life Sci. J., 8: 245 - 252

Navone, G.T., Sardella, N.H., Timl, J.T. (1998): Larvae and adults of Hysterothylacium aduncum (Rudolphi, 1802) (Nematoda: Ani- sakidae) in fishes and crustaceans in the South West Atlantic. Parasite, 5:127 - 136

Nikolaeva, V.M., Shramova, G.F. (1975): The survival of nematode larvae under different temperature conditions. Biol. Morya, 34: 110 - 118 (In Russian with English summary)

Osmanov, S.U. (1940): Materials on parasite fauna of the Black Sea fishes. Uchenie zapiski Leningradskogo Gospedinstituta, Kafedr Zoologii i Darvanizma 30: 187 - 266 (In Russian with English summary)

Özer, A. (2007): Metazoan parasite fauna of the round goby Neogobius melanostomus Pallas, 1811 (Perciformes: Gobiidae) collected from the Black Sea coast at Sinop, Turkey. J. Nat. Hist., 41: 483 - 492. DOI: 10.1080/00222930701234361

Özer, A., Öztürk, T. (2005): Dactylogyrus cornu Linstow, 1878 (Monogenea) Infestations on the Vimba (Vimba vimba tenella Nordmann, 1840) in relation to the host factors. Turkish J. Vet. Anim. Sci., 29: 1119 - 1123

Özer, A., Olguner, A.M. (2013): Metazoan parasites of some marine fish species collected at the Sinop coasts of the Black Sea. Ege J. Fish. Aquat. Sci., 30: 93 - 97. DOI: 10.1080/00222930701234361 Özer, A., Öztürk, T., Erdem, O. (2000): A study on the Hysterothylacium aduncum (Nematoda: Anisakidae) infections in the whiting Merlangius merlangus euxinus. In National Fisheries Symposium 2000, Sinop, Proceedings and Abstract Book, pp. 632 - 641

Özer, A., Olguner, A.M., Ünsal, G. (2009): Comparative infections of Hysterothylacium aduncum (Rudolphi, 1802) in Merlangius merlangus and Maena smaris collected from Sinop coasts of Turkey. In XV. National Fisheries Symposium 2009, Rize, Proceedings and Abstract Book, p.293 (Abstract only)

Özer, A., Kornyychuk, Y., Öztürk, T., Yurakhno, V., Kornyushin, V. (2012) Parasite fauna of the Black Sea whiting, Merlangius merlangus L., 1758 and it's dynamics in relation with some host factors. In XI European Multicolloquium of Parasitology (EMOP XI) (Cluj-Napoca, Romania, July 25 - 29, 2012), p. 395 (Abstract only) Özer, A., Öztürk, T., Kornyushin, V., Kornyychuk, Y., Yurakhno, V. (2014): Grillotia erinaceus (van Beneden, 1858) (Cestoda: Trypanorhyncha) from whiting in the Black Sea, with observations on seasonality and host-parasite interrelationship. Acta Parasitol., 59: 420 - 425. DOI: 10.2478/s11686-014-0261-z

ÖzTÜRK, T. (2005): Determination of parasite fauna of flounder Platichthys flesus L., 1758 and toothcarp Aphanius chantrei Gaillard, 1895 living in Sarıkum Lagoon (Sinop, Turkey). Ph.D. thesis. Ondokuz Mayıs University, Turkey

Pekmezcl, G.Z., BölüKBAŞ, C.S., Gürler, A.T., Onuk, E.E. (2013): Occurrence and molecular characterization of Hysterothylacium aduncum (Nematoda: Anisakidae) from Merlangius merlangus euxinus and Trachurus trachurus off the Turkish coast of Black Sea. Parasitol. Res., 112: 1031 - 1037. DOI: 10.1007/s00436012-3227-9

Petter, A., Maillard, C. (1988): Larves d'ascarides parasites de poissons en Mediterranee occidentale. Bull. Mus. Natl. Hist. Nat. Paris, 4e ser., 10 (Section A): 347 - 369 
PogoreltceVA, T.P. (1952): Data on parasite fauna of fishes off the north-western part of the Black Sea. Proc. Inst. Zool., 8: 100 - 120 (In Ukrainian)

Reiczigel, J., RyzsA, L. (2005): Quantitative Parasitology 3.0. Budapest [computer software]

Rello, F.J., Adroher, F.J., Valero, A. (2008): Hysterothylacium aduncum, the only anisakid parasite of sardines (Sardina pilchardus) from the southern and eastern coasts of Spain. Parasitol. Res., 104: 117 - 121. DOI: 10.1007/s00436-008-1168-0

ROHDE, K. (1993): Ecology of marine parasites: An introduction to marine parasitology. 2nd Edition, CAB International, UK SмITH, J.W. (1983): Anisakis simplex (Rudolphi 1809, det. Krabbe 1878) (Nematoda: Ascaridoidea): morphology and morphometry of larvae from euphausiids and fish, and a review of the life-history and ecology. J. Helminthol., 57: 205 - 224. DOI: 10.1017/ S0022149X00009512

Smith, J.W., Wootten, R. (1978): Anisakis and anisakiasis. Adv. Parasitol., 16:93-163. DOI:10.1016/S0065-308X(08)60573-4

SkURatovskaya, E.N., YuRakHno, V.M., Zavyalov, A.V. (2013): The influence of parasitic infection on the Black Sea whiting Merlangius merlangus euxinus (Gadidae) morphophysiological and biochemi- cal parameters. Vestnik Zool., 47: 309 - 317

SVETOVIDOV, A.N. (1964): Handbook of the fauna of the USSR, fishes of the Black Sea. Izdatel'stvo Nauka, Moscow

Tepe, Y., OĞuz, M.C. (2013): Nematode and acanthocephalan parasites of marine fish of the eastern Black Sea coasts of Turkey. Turkish J. Zool., 37: 753 - 760. DOI:10.3906/zoo-1206-18

Timi, J.T., Luque, J.L., Sardella, N.H. (2005): Parasites of Cynoscion guatucupa along South American Atlantic coasts: Evidence for stock discrimination. J. Fish Biol., 67: 1603-1618. DOI: 10.1111/j.1095-8649.2005.00867.x

Valero, A., Martin-Sanchez, J., Reyes-Muelas, E., Adroher, F.J. (2000): Larval anisakids parasitizing the blue whiting, Micromesistius poutassou, from Motril Bay in the Mediterranean region of southern Spain. J. Helminthol., 74:361-364. DOI: 10.1017/ S0022149X00000536

Zavyalov, A.V. (2013): Seasonal dynamic of whiting Merlangius merlangius euxinus infestation by nematode Hysterothylacium aduncum (Rud., 1802) in different regions of the Crimean coast. Ribnoe Hozjaystvo Ukraini, 1: 24 - 33 (In Russian with English summary) 